\title{
The Illogical Logic in Alice's Adventures in Wonderland
}

\author{
Najah A. Almabrouk \\ Department Of English Language And Literature \\ Istanbul Aydin University, \\ Besyol Mah. Inonu Cad. No: 40. 34295 Sefakoy \\ Kücükcekmece, Istanbul, Turkey.
}

\begin{abstract}
One Property Of Natural Language Is That It Has A Logical Structure. Logic In Linguistics Can Be Perceived As That Hidden Tie Which Links Linguistic Devices To The Semantic Meanings Of Sentences. This Qualitative Descriptive Case Study Tried To Shed Light On The Relation Between Logic And Language, Mainly The Logic-Based Semantic Relation Of Entailment. It Explored Logic-Based Semantics In Literary Texts Particularly Lewis Carroll's Masterpiece Of Alice's Adventures In Wonderland. The Results Showed That Alice's Utterances Alone Were Rich In Entailments With 46 Examples found Across The 12 Chapters Of The Novel. All Of The Entailments Were Of Syntactic Type Following The Four Logical Rules Of Inference: Modus Ponens, Modus Tollens, Hypothetical Syllogism And Disjunctive Syllogism. Through The Use Of Entailment, Carroll Was Able To Produce Three Main Illocutions: Criticizing, Questioning And Emphasizing In Which He Remarked On Social Values, The Human Nature, Authority, Politics, Physics, Logic And Identity.
\end{abstract}

Keywords: Logic, Semantics, Truth Conditions, Entailment, Presupposition, Illocutions, Speech Act Theory, Rules Of Inference

\section{Introduction}

One Property Of Natural Language Is That It Has A Logical Structure. Logic In Linguistics Can Be Perceived As That Hidden Tie That Links Linguistic Devices To The Semantic Meanings Of Sentences. Holding Between Cognition And meanings, It Functions As A Tool To Disambiguate Utterances Through Applying A Set Of Logic Rules (Saeed, 2003). However, Literary Texts Do Not Always Abide By The Rules Of Logic Mostly For Stylistic Purposes Such As The Use Of Irony, Hyperbole, Metaphor And Many More. Violating The Rules Of Logic Leads To A Semantic Gap That May Affect The Meaning of Sentences And Create A Kind Of Linguistic Riddles To Be Resolved By The Reader Through Decoding The Language Via The Application Of Logic. Viewed As A System Of Calculation Rules, Montague (1974) Argues That Logic Can Help Readers To Represent Sentence Meaning (As Cited In Saeed, 2003).

Under The Umbrella Of Semantics, This Study Tried To Shed Light On The Relation Between Logic And Language, Mainly The Semantic Relations That Holds Between Sentences. It Explored logic-Based Semantics In Literary Texts Particularly Lewis Carroll's Masterpiece Of Alice's Adventures In Wonderland. This Paper Focused On The Broad Sense Of Logic With Confinement To Truth-Conditional Semantics And Did Not Delve Into More Sophisticated Approaches To Logic Such As Formal Semantics. Thus, This Study Attempted To Answer Two Main Questions: How Did Carroll Use Logic in A Context Of A Fantasy World Of Nonsense? And, What Are The Semantic Implications That Resulted From The Truth-Based Semantic Relations Found In The Novel? On The Basis Of The Study Of Logic,Which Dates Back To The Great Greek Philosopher Aristotle, This Research Paper Adopts The Truth-Based Approach To Meaning Under The Theoretical Framework Of Semantics. The Focus Of This Study Was On One main Truth-Based Semantic Relation: Entailment. Thus, Brief Introductions To Logic, Truth, Entailment And Presupposition, Which Is Related To Entailment, Are Given Below.

\section{Literature Review}

\subsection{Logic And Truth}

Saeed (2003) Provided A Good Explanation To The Notion Of Logic Claiming That Logic Is About Finding The Principals Of Valid Argument And Inference. He Used An Example Of Aristotle'smodus Ponens Rule Which Is A Three-Step Argument When The Truth Of A Given Proposition Is Derived From The Truth Of Two Previous Dependent Propositions Such As In The Following Example: 
If John Has Been Rewarded, Then He Has Won The Game

John Has Been Rewarded

John Has Won The Game

If The Two Propositions Over The Line (Called The Premises) Are True Then The Proposition Under The Line (Called The Conclusion) Is Also True. There Are Three Other Rules Of Valid Inference: Modus Tollens, The Hypothetical Syllogism And The Disjunctive Syllogism (Saeed, 2003).

The Modus Tollens Rule Implies That If The Second Proposition Of The First Premise Is Negated Then The First Proposition Of The Premise would Also Be Negated Which Means That If The Second Proposition Is Untrue Then The First One Is Also False.

If John Has Been Rewarded, Then He Has Won The Game

John Has Not Won The Game

John Has Not Been Rewarded

The Hypothetical Syllogism Rule Includes A New Conditional statement In The Second Premise and Thus The Conclusion Will Also Entail The Truth Of The Added Hypothetical Proposition Along With The First Proposition Of The First Premise As In The Example Below:

If John Has Been Rewarded, Then He Has Won The Game

If John Has Won The Game, Then He Is Happy

If John Has Been Rewarded, Then He Is Happy

The Last Rule Of Inference, Disjunctive Syllogism, Is About The Truth Of Either The First Proposition Of The First premise Or The Second Part Of The First Premise. With The Use Of Preposition Or A Conditional Statement Is Used In The Premise. It Suggests That When The Second Premise is Negated Then The Conclusion Will Point To The Truth Of The Second Proposition Of The First Premise only As In The Following Example:

John Is At School Or He Is At Home

John Is Not At School

John Is At Home

Saeed (2003) Opines That In Order To Determine The Truth Of Sentences One Has To Have Two Types Of Knowledge. The First Is Contextual Facts About The Speaker Or The Names And Objects Involved In The Utterance And The Second Is Scientific Facts About The Universe. Whether A Sentence Is True Or False Is Called Its Truth Value; It Can Be Assigned By The Sentence's Truth Conditions, Which Are The Facts Obtained From Reality: Either Contextual Or Scientific (Saeed, 2003). To Show That The Truth Relationships That Hold Between Sentences Apply To Any Kind Of Sentences Semanticists Came Up With A Logical Notation Of A Developed Formula To Represent Propositions Unambiguously (Hurford Et Al., 2007). The Notation Includes Symbols (Like \& Which Stands For And, V For Or, And For Not) For Building Up Logical Formulas Where A Lower-Case Letter (P, Q, R, Etc.) Stands For Different Propositions (Saeed, 2003). If A Proposition Is Affirmative Then It Is Represented By $\mathbf{P}$ And If It Is Negative It Is Represented By $\sim$ P. Truth Tables Are Used By Logicians To Indicate The Relations Between Propositions. When A Proposition Is True Then Its Truth Value Is Represented By The Letter T And When It Is False Then Its Truth Value Is Represented By F. This Is Elaborated In The Following Example:

a. John Has Won The Game ( Proposition P)

b. John Has Not Won The Game (Proposition Q)

A Truth Table Can Be Formed For These Two Sentences And It Would Be Read As When Proposition P Is True (T) Then Proposition $\mathbf{Q}$ Is False (F) And, Vice Versa, When $\mathbf{P}$ Is False (F) Then $\sim \mathbf{Q}$ Is True (T). Below Is The Truth Table For The Above Example:

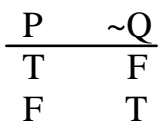

A Number Of Connectives Such As And and or Are So Significant In The Study Of Logic Due To Their Predictable Effect On The Truth Conditions Of Compound Statements; This Is Because The Truth Value Of A Compound Statement Can Be Predicted From The Truth Of The Constituent Statements (Hurford Et Al., 2007). A Truth Table For Connective and is Given Below: 


\begin{tabular}{ccc}
$\mathrm{P}$ & $\mathrm{Q}$ & $\left(\mathrm{P}^{\wedge} \mathrm{Q}\right)$ \\
\hline $\mathrm{T}$ & $\mathrm{T}$ & $\mathrm{T}$ \\
$\mathrm{T}$ & $\mathrm{F}$ & $\mathrm{F}$ \\
$\mathrm{F}$ & $\mathrm{T}$ & $\mathrm{F}$ \\
$\mathrm{F}$ & $\mathrm{F}$ & $\mathrm{F}$
\end{tabular}

There Are Two Kinds Of Logical Connective Or: The Inclusive Or And The Exclusive Or. The Inclusive Or Is Common In Sentences Such As I Will Give My Friend A Book Or A Magazine. The Truth Table For The Inclusive Or Is Provided Below:

\begin{tabular}{ccc}
$\mathrm{P}$ & $\mathrm{Q}$ & $(\mathrm{P} \mathrm{V} \mathrm{q})$ \\
\hline $\mathrm{T}$ & $\mathrm{T}$ & $\mathrm{T}$ \\
$\mathrm{T}$ & $\mathrm{F}$ & $\mathrm{T}$ \\
$\mathrm{F}$ & $\mathrm{T}$ & $\mathrm{T}$ \\
$\mathrm{F}$ & $\mathrm{F}$ & $\mathrm{F}$
\end{tabular}

However, The Exclusive Or Which Is Symbolized By Ve can Be Seen In Sentences Such As In The Sentence You Will Do The Homework Or You Will Be Punished. In This Example If Both Propositions Are True The Compound Statement With Or Cannot Be True Because The Sentence Has An Implication That (But Not Both: Doing The Homework And Being Punished) (Saeed, 2003). Therefore If One Does The Homework It Will Be Illogical And Unfair To Get Punished While He Or She Has Fulfilled The Duty Being Asked To Do. This Connective Has A Different Truth Table:

\begin{tabular}{ccc}
$\mathrm{P}$ & $\mathrm{Q}$ & (P Ve q) \\
\hline $\mathrm{T}$ & $\mathrm{T}$ & $\mathrm{F}$ \\
$\mathrm{T}$ & $\mathrm{F}$ & $\mathrm{T}$ \\
$\mathrm{F}$ & $\mathrm{T}$ & $\mathrm{T}$ \\
$\mathrm{F}$ & $\mathrm{F}$ & $\mathrm{F}$
\end{tabular}

Another Connective Is Called Material Implication And Symbolized As $\rightarrow$. It Can Be Found In Conditional Sentences As If It Rains, I Will Visit My Friend. The Sentence Can Be Only False If $\mathbf{P}$ Is $T$ And $\mathbf{Q}$ Is F. If $\mathbf{P}$ Is $F$ And $\mathbf{Q}$ Is $T$ Then The Compound Statement Is T Because $\mathbf{P}$ Is A Sufficient Truth Condition For $\mathbf{Q}$ But Not A Necessary Condition. It Has The Following Truth Table:

\begin{tabular}{ccc}
$\mathrm{P}$ & $\mathrm{Q}$ & $(\mathrm{P} \rightarrow \mathrm{Q})$ \\
\hline $\mathrm{T}$ & $\mathrm{T}$ & $\mathrm{T}$ \\
$\mathrm{T}$ & $\mathrm{F}$ & $\mathrm{F}$ \\
$\mathrm{F}$ & $\mathrm{T}$ & $\mathrm{T}$ \\
$\mathrm{F}$ & $\mathrm{F}$ & $\mathrm{T}$
\end{tabular}

There Is Also A Related Connective Called Biconditional, Symbolized By $\equiv$. The Biconditional Reflects A Statement Where The Sentence Is True If And Only If Both Of $\mathbf{P}$ And $\mathbf{Q}$ Are Either True Or False Because $\mathbf{P}$ Is A Necessary Condition For $\mathbf{Q}$. This Means That $\mathbf{P}$ Is T If And Only If $\mathbf{Q}$ Is $\mathrm{T}$ And This Relation Can Be Abbreviated As Piffq. It Can Be Illustrated In Sentences Such As I Will Leave My Country If And Only If I Am Obliged To. It Has The Following Truth:

\begin{tabular}{ccc}
$\mathrm{P}$ & $\mathrm{Q}$ & $(\mathrm{P} \equiv \mathrm{Q})$ \\
\hline $\mathrm{T}$ & $\mathrm{T}$ & $\mathrm{T}$ \\
$\mathrm{T}$ & $\mathrm{F}$ & $\mathrm{F}$ \\
$\mathrm{F}$ & $\mathrm{T}$ & $\mathrm{F}$ \\
$\mathrm{F}$ & $\mathrm{F}$ & $\mathrm{T}$
\end{tabular}

Thus The Abovementioned Four Valid Inference Rules Have The Following Representations: Modus Ponens: $\frac{P Q}{Q}$, Modus Tollens: $\frac{\stackrel{P \rightarrow Q}{\sim}}{\sim P}$, Hypothetical Syllogism: $\frac{\substack{P \rightarrow Q \\ Q \rightarrow R}}{P \rightarrow R}$, And Disjunctive Syllogism: $\frac{\stackrel{P \vee Q}{\sim P}}{Q}$. 
Given That, It Can Be Concluded That Sentences Have Truth Values Where Truth Is Of Different Types. The Types Include Empirical Truth Which Depends On Reality And The Knowledge Of The World And Necessary Truth Such As In Tautologies Where Sentences Are Always True In Their Literal Meanings. However,Tautologies Cannot Be Denied Unless A Contradiction Is Forced. Contradiction Occurs When Two Sentences Are Opposite Or Contradictory To Each Other. Like Necessary Truth, Analyticity Is Another Type Of Truth Where The Truth Is Derived From The Meaning Relations In The Sentence Disregardthe Knowledge About The World (Saeed, 2003).

He Also Elaborated That In Comparison To Analytic Statements, Synthetic Statements Are True But Not Necessary True Because They Depend On The Facts Of The World In Given Situations.

\subsection{Entailment And Presupposition}

Entailments And Presupposition Are Two Related Semantic Relations. Entailment Is So Important For The Theories Of Meanings About Sentence Relations (Lyons, 1995). It Is A Semantic Relation Between Sentences Whereby The Truth Of A Certain Sentence Necessary Follows From The Truth Of The Preceding Sentence(Crystal, 1998). In Other Words, A Sentence $\mathbf{P}$ Entails Sentence $\mathbf{Q}$ When The Truth Of The First $\mathbf{P}$ Guarantees The Truth Of The Second $\mathbf{Q}$, And The Falsity Of The Second $\mathbf{Q}$ Guarantees The Falsity Of The First P(Saeed, 2003). This Can Be Clarified By This Example:

The Policeman Killed The Criminal.

The Criminal Died.

The Truth Table For Entailment Then Is Represented By The Following:

$$
\begin{aligned}
& \mathrm{P} Q \\
& \hline \mathrm{T} \rightarrow \mathrm{T} \\
& \mathrm{F} \rightarrow \mathrm{T} \text { Or } \mathrm{F} \\
& \mathrm{F} \leftarrow \mathrm{F} \\
& \mathrm{T} \text { Or } \mathrm{F} \leftarrow \mathrm{T}
\end{aligned}
$$

The Semantic Relation Of Entailment Can Be Deducted Without Checking Any Fact Of The World, Rather It Depends On The Linguistic Structure Or The Lexicon As The Source Can Be Lexical Or Syntactic (Saeed, 2003). For Example, Lexical Relationships Such As Hyponymy Is A Common Source Of Lexical Entailment. Syntactic Entailment However Derives From Active And Passive Forms Of The Same Sentence Resulting In Paraphrases Which Are Sentences That Mutually Entail Each Other (Finch, 2000). Entailment Also Can Be Generated By Sentence Relations Of Synonymy When Two Sentences Entail Each Other And Contradiction Which Can Be Formed By Negation Or Lexical Relations Such As Antinomy. Presupposition On The Other Hand Is Another Semantic Relation Which Is Mainly About Making Assumptions And It Is Related To The Speaker's Meaning (Saeed, 2003). The Study Argues That There Are Two Approaches To Presupposition One Is Semantic Where Sentences Are Viewed As External Objects And The Meaning Is An Attribute To Sentences. In Other Words, Semantic Presupposition Is Related To The Conventional Meaning Of Words. The Second Is A Pragmatic Approach To Presupposition Where Sentences Are Dealt With As Utterances Of Individuals In A Context Of Communication. It Is Viewed As The Speaker's Actions (Indarti, 2015). Below Is An Example Of Presupposition:

\section{John's Sister Has Got Married John Has A Sister}

The First Sentence Presupposes The Second Sentence As The Meaning Of John Has A Sister Can Be Assumed From The Background Meaning Of John's Sister Has Got Married. Because This Paper Is Interested In The Semantic Presupposition, The Truth Table For The Semantic Presupposition Only Is Given Below:

\begin{tabular}{lll}
$\mathbf{P}$ & $\mathbf{Q}$ \\
\hline $\mathrm{T}$ & $\rightarrow$ & $\mathrm{T}$ \\
$\mathrm{F}$ & $\rightarrow$ & $\mathrm{T}$ \\
$\mathrm{T}$ Or F & $\leftarrow$ & $\mathrm{T}$
\end{tabular}

In Sum, Entailment Is A Logical Implication Relation That Holds Between Propositions $\mathbf{P}$ And $\mathbf{Q}$ Such That Whenever $\mathbf{P}$ Is True, $\mathbf{Q}$ Is Also True. However, Presupposition Is A Pragmatic Relation That Holds Between The Speaker And The Proposition (Tember\& Frank, 2013).Past Studies Such As Jafar (2008) Explored The Notion Of Entailment And The Relation Between Entailment And Hyponymy. It Also Discussed presupposition And Shed Light On The Difference Between Presupposition, Entailment, Synonymy And Supposition. The Objective Of The Study Was To Assess Whether Iraqi EFL University Students Were Able To Recognize entailment And Presupposition And To Identify The Points Of Difficulty They Encountered In Using Entailment And Presupposition As Well As To Find Out 
The Reasons Of And Solutions For Students' Errors. The Results Of The Experimental Study Showed That Most Iraqi EFL University Students Were Unable To Differentiate Between Entailment And Presupposition. This Actually Proves That A Clear-Cut Distinction Between The Two Semantic Relations Is Not Easy.To Solve This Problem, Saeed (2009) Suggested A Negation Test And Argues That Entailments Fail The Negation Test While Presuppositions Survive The Test (As Cited In Indarti, 2015).

This Means That If The Entailing Sentence Is Negated, The Entailed Sentence Becomes False While If The Presupposing Sentence Is Negated, The Presupposed Sentence Will Remain True. Indarti (2015) Conducted A Study In Which He Discussed Entailment And Presupposition Under The Negation Test. The Researcher Tested Pairs Of Utterances In Garfield The Cat Comic Strips. The Qualitative Descriptive Study Aimed At Showing The Difference Between The Two Semantic Relations Using A Negation Test. The Result Of The Study Proved The Efficiency Of The Negation Test. The Study Concluded That The Difficulty Of Distinguishing Entailment And Presupposition Can Be Successfully Solved By The Negation Test. The Current Study However Explored The Use Of The Logic-Based Semantic Relation Of Entailment In Alice's Adventures In Wonderland. It Aimed At Finding Out How Logic Was Used In The Novel Despite The Fact That Most Of Its Events And Utterances Seem Illogical As They Take Place In An Imaginary World. In Other Words, It Tried To Determine Whether Carroll Followed The Four Logic-Based Rules Of Inference And Whether They Were Valid Or Invalid. Moreover, It Also Saught To Explore The Semantic Implications That Result From The Use Of Logic In An Apparently Illogical Context.

\section{Methodology}

\subsection{Research Design And Material Selection}

This Research Is A Qualitative Descriptive Case Study That Semantically Analyzed The Well-Known Novel Of Lewis Carroll: Alice's Adventures In Wonderland. This Novel Was Particularly Selected Because It Is Famous For Nonsense And Follows A Different System Of Logic Where Events Take Place In A Fantasy Illogical World And Actions Do Not Follow The Natural Reasoning Of Normal Life Being So Far From Reality; And, Because It Was Written By A Logician And A Mathematician, Charles Lutwidge Dodgson Who Is Known By His Pen Name Lewis Carroll, Which Makes It A Good Discourse For Logic-Based Semantic Analysis.

\subsection{Data Analysis}

This Paper Adopted Semantic Discourse Analysis. Dijk (1985) Argues That Semantic Discourse Analysis Has An Extensional Or Referential Dimension That Seeks The Knowledge On The References Of Sequences Of Sentences In A Discourse. He Opined That Logic Identified The Sentence Reference With A Truth Value (Whether True Or False), Claiming That Truth Values Are Also Assigned To Compound Propositions Based On The Meanings Of The Connectives Between Them. Thus, Discourse Semantics Determine The Rules That Assign A Truth Value To The Whole Discourse On The Basis Of The Truth Values Of Individual Sentences Dijk (1985). Given That, This Research Followed Semantic Discourse Analysis To Study The Truth-Based Semantic Relation: Entailment. Seven Procedures Were Pursued In This Paper In Order To Analyze The Novel Semantically. First, The Novel Was Read Thoroughly And Utterances Were Identified. Second, Utterances Were Filtered And The Ones That Included Entailment Were Determined.This Was Done By Searching For Conditional Sentences As Well As Other Affirmative Or Negative Sentences That Contained Words Like Must, Then And When. Other Utterances That Included Some Kind Of Questions Were Also Selected For Analysis After Being Converted To The Form Of Conditional Sentences. Third, Alice's Utterances Alone Were Selected For Data Analysis Due To The Large Text Of The Novel. In Order To Distinguish Entailments From Presuppositions, The Negation Test Was Applied. Fourth, The Selected Utterances Were Analyzed With Accordance To Logic-Based Semantics Under The Framework Of Semantic Discourse Analysis. Fifth, The Analyzed Utterances Were Classified Whether They Contain Valid Or Invalid Arguments Based On The Four Valid Inference Rules: Modus Ponens, Modus Tollens, Hypothetical Syllogism And Disjunctive Syllogism. Sixth, The Semantic Implications That Resulted From The Analyzed Utterances Were Identified Based On The Illocutions Performed In The Utterances. This Was Done By Adopting The Framework Of The Pragmatic Speech Act Theory By John Austin Who Claims That Utterances Perform Actions Or What He Called Illocutions (As Cited In Hiani, 2015). Finally, The Seventh Step Was Identifying The Type Of Entailment Whether Syntactic Or Lexical.

\section{Results}

The Results Of This Study Were Reached By Following The Above Mentioned Seven Procedures. Semantic Discourse Analysis Of Alice's Utterances In The Great Fantasy Novel Of Alice's Adventures In Wonderland Showed That The Selected Utterances Were Rich In Logic-Based Semantic Relations: Particularly Entailment. A Total Of 46 Utterances That Included Entailment Were Found Across The 12 Chapters Of The Novel. All Of The Entailments Found In The Text Were Of The Syntactic Type And Followed The Four Logical Rules Of Inference: Modus Ponens, Modus Tollens, Hypothetical Syllogism And Disjunctive Syllogism. Modus Ponens Was Used In 21 Entailments; Hypothetical 
Syllogism Was Used In 12 Entailments; Modus Tollens Was Used In 7 Entailments, And Disjunctive Syllogism Was Used In 6 Entailments. The Results Of The Analyzed Utterances Were Distributed To Four Tables Attached Below And Categorized Based On The Four Inference Rules.

Table 1 Shows That 14 Out Of 21 Modus Ponens Entailments Were Logically Formed By Valid Arguments And That The Remaining 7 Entailments Were Logically Invalid. Whether The Arguments Were Valid Or Invalid Had No Significant Impact On The Semantic Implications Of Utterances. In Other Words, Valid And Invalid Arguments Both Carried Meanings And Conveyed Messages To The Reader. The Only Difference Was That The Truth Values Of Valid Arguments Were Always True And That The Truth Values Of Invalid Arguments Were Always False. The Semantic Implications That Resulted From Modus Pones Entailments Are Listed In The Table.

Table 2 Shows That All Hypothetical Syllogism Entailments Were Logically Formed By Valid Arguments. The Semantic Implications That Resulted From Hypothetical Syllogism Entailments Are Given In The Table.

Table 3 Shows That All Modus Tollens Entailments Were Logically Formed By Valid Arguments. The Semantic Implications That Resulted From Modus Tollens Entailments Are Included In The Table.

Table 4 Shows That Five Out Of Six Disjunctive Syllogism Entailments Were Logically Formed By Valid Arguments. Whether The Arguments Were Valid Or Invalid Had No Significant Impact On The Semantic Implications Of Utterances. In Other Words, Valid And Invalid Arguments Both Carried Meanings And Conveyed Messages To The Reader. The Only Difference Was That The Truth Values Of Valid Arguments Were Always True And That The Truth Values Of Invalid Arguments Were Always False. The Semantic Implications That Resulted From Hypothetical Syllogism Entailments Are Shown In The Table.

\section{Discussion}

The Results Showed That The Analyzed Utterances Of The Novel Contained Truth-Based Semantic Relations: Mainly Syntactic Entailment. The Entailments That Were Found In The Novel Were Logically Formed In Consistence With The Four Logic Rules Of Inference: Modus Ponens, Modus Tollens, Hypothetical Syllogism And Disjunctive Syllogism. Most Of The Logical Arguments That Were Used To Build Up The Entailments Were Valid Arguments.This Means That The Truth Values Of Most Of The Arguments Were True As 39 Out Of 46 Entailments Were Logically Formed By Valid Rules Of Inference. After Applying Semantic Discourse Analysis On The Text Of The Masterpiece Of Art: Alice's Adventures Of Wonderland, It Turned Out That Entailment Is So Important To Logic Such That It Can Function As A Tool To Build Up And Create Logical Arguments Out Of Imagination And Hypothetical Situations That Exist In A Virtual Fantasy World. Even Though Such A World Does Not Contain Real Actions Or Events And Is Far From Reality, Logic Still Can Be Applied To End Up With Scenarios With Its Own Made-Up Rules Of Logic Within A Different Reasoning System. Out Of This Creative Methodology To Draw Pictures And Images Of A World Created By The Imagination Of A Little Child, Carroll Could Convey Certain Messages To The Reader By The Semantic Implications That Resulted From His Use Of The Logic-Based Semantic Relation Of Entailment Found In Alice's Utterances In The Novel. According To The Speech Act Theory Which Was Proposed By Austin (1962) As Cited In Hiani (2015), Utterances Can Perform Actions Through Three Main Acts. First, Locutionary Act, Which Is The Lateral Meaning Of An Utterance. Second, Illocutionary Act, Which Is The Intention Of The Speaker In Making The Utterance (Saeed 2003). Third, Perlocutionary Act, Which Is The Effect Of The Speaker's Utterance On The Hearer. Through The Use Of Entailment Carroll Was Able To Produce Three Main Illocutions: Criticizing, Questioning And Emphasizing. In 27 Entailments, Carroll Performed The Speech Act Of Criticizing In Which He Criticized The Old Style Of Writing Books Without Pictures. He Also Criticized The Human Nature, Authority, Politics, And Social Values As Well As Human Capabilities For Comprehending Language And Logic. He Performed The Act Of Emphasizing In 11 Entailments Where He Emphasized The Importance Of Sciences Such As Logic And Mathematics In Addition To Social Values And Rights Such As Silence, Objection And Freedom Of Speech. He Also Emphasized The Importance Of The Question Of How As Well As The Importance Of Zero In Mathematics. In Addition, He Emphasized The Relation Between Feelings And Body Changes. An Interesting Result Was That Carroll Highlighted Not Only The Importance But Also The Unimportance Of Some Values Or Human Practices Such As Wishes And The "Perfect Size" As Long As It Fits. The Third Speech Act That Was Performed By Carroll Is Questioning. It Was Found In 8 Entailments Which He Used To Question Identity Based On Body Changes, Beauty And Education. He Also Questioned Physics And Meanings Of Words Such As In The Utterance Do Cats Eat Bats? Or Do Bats Eat Cats?

However, Further Research Is Urged For Exploring Entailment And Presupposition Together In The Utterances Of All Of The Characters In The Novel Not Only Alice's.This Is Important Especially That The Other Characters Are Made Up By The Imagination Of Alice And Thus Being Unreal Makes Their Utterances A Good Source For More Illogical,Or Rather Logical, Arguments. 


\section{References}

Carroll, L., \& In Gardner, M. (2004). The Annotated Alice: The Definitive Edition, Marten Gardner (Ed.) New York: Norton.

Crystal, D. (1998). A Dictionary Of Linguistics And Phonetics. Oxford: Blackwell Publisher Ltd.

Dijk, T. A. V. (1985). Semantic Discourse Analysis. Handbook Of Discourse Analysis (2) 103-136.

Finch, G. (2000). Linguistic Terms And Concepts. London: Macmillan Press LTD.

Hiani, K. (2015). Performing Speech Acts Among Moroccan EFL Advanced Learners. Procedia- Social And Behavioral Sciences, (199) $479-485$.

Hurford Et.Al. (2007). Semantics: A Coursebook. Cambridge: Cambridge University Press.

Indarti, G. A. (2015). Distinguishing Entailment And Presupposition Under Negation Test. Language And Language Teaching Journal, 18(01), 27-38. Doi:10.24071/Llt.2015.180104.

Ja'far, A. A. (2008). Entailment And Presupposition. Babylon University.

Lyons, J. (1995). Linguistic Semantics: An Introduction. Cambridge: Cambridge University Press.

Saeed, J. (2003). Semantics (2nd Ed). Blackwell Publishers, Malden, Mass.

Tremper, G, \& Frank, A. (2013). A Discriminative Analysis Of Fine-Grained Semantic Relations Including Presupposition: Annotation And Classification. Dialogue \& Discourse, 4 (2).

\section{Appendix}

\begin{tabular}{|c|c|c|c|c|c|c|c|}
\hline $\begin{array}{l}\text { No. } \\
\text { And } \\
\text { Page }\end{array}$ & Utterance & Analysis & $\begin{array}{l}\text { Form } \\
\text { ula }\end{array}$ & Rule & $\begin{array}{l}\text { Validit } \\
\mathbf{y}\end{array}$ & $\begin{array}{l}\text { Semantic } \\
\text { Implications }\end{array}$ & Type \\
\hline (P.14) & $\begin{array}{l}\text { What Is The Use } \\
\text { Of A Book } \\
\text { Without Pics Or } \\
\text { Conversation? }\end{array}$ & $\begin{array}{l}\text { If A Book Has } \\
\text { No Pictures Or } \\
\text { Conversations, } \\
\text { Then It Is Of } \\
\text { No Use. }\end{array}$ & $\begin{array}{l}P Q \\
P Q\end{array}$ & $\begin{array}{l}\text { Modus } \\
\text { Ponens }\end{array}$ & Valid & $\begin{array}{l}\text { Criticizing How } \\
\text { Books Used To } \\
\text { Be Written } \\
\text { (Without } \\
\text { Pictures) }\end{array}$ & Syntactic \\
\hline $\begin{array}{l}2 \\
\text { (P.14) }\end{array}$ & $\begin{array}{l}\text { I Wonder How } \\
\text { Many Miles I've } \\
\text { Fallen This } \\
\text { Time? I Must Be } \\
\text { Getting } \\
\text { Somewhere Near } \\
\text { The Center Of } \\
\text { The Earth. }\end{array}$ & $\begin{array}{l}\text { If I Have } \\
\text { Fallen That } \\
\text { Long, Then } \\
\text { I Must Be Near } \\
\text { The Center Of } \\
\text { The Earth. }\end{array}$ & $\begin{array}{l}P Q \\
\frac{P}{Q}\end{array}$ & $\begin{array}{l}\text { Modus } \\
\text { Ponens }\end{array}$ & Valid & $\begin{array}{l}\text { Questioning } \\
\text { Physics }\end{array}$ & Syntactic \\
\hline $\begin{array}{l}3 \\
\text { (P.14) }\end{array}$ & $\begin{array}{l}\text { If I Shall Fall } \\
\text { Right Through } \\
\text { The Earth, How } \\
\text { Funny It'll } \\
\text { Seem... }\end{array}$ & $\begin{array}{l}\text { If I Fall Right } \\
\text { Through The } \\
\text { Earth, Then } \\
\text { It Will Be } \\
\text { Funny. }\end{array}$ & $\begin{array}{l}P Q \\
\frac{P}{Q}\end{array}$ & $\begin{array}{l}\text { Modus } \\
\text { Ponens }\end{array}$ & Valid & $\begin{array}{l}\text { Criticizing } \\
\text { Physics Through } \\
\text { Humor }\end{array}$ & Syntactic \\
\hline $\begin{array}{l}4 \\
\text { (P.15) }\end{array}$ & $\begin{array}{l}\text { Dinah, My Dear, } \\
\text { I Wish...You } \\
\text { Might Catch A } \\
\text { Bat. }\end{array}$ & $\begin{array}{l}\text { If Dinah Is } \\
\text { Hear, Then It } \\
\text { Might Catch A } \\
\text { Bat }\end{array}$ & $\begin{array}{l}P Q \\
\sim P \\
\sim Q\end{array}$ & $\begin{array}{l}\text { Modus } \\
\text { Ponens }\end{array}$ & Invalid & $\begin{array}{l}\text { Emphasizing } \\
\text { That Wishes Are } \\
\text { Of No Use }\end{array}$ & Syntactic \\
\hline $\begin{array}{l}5 \\
\text { (P.16) }\end{array}$ & $\begin{array}{l}\text { What A Curious } \\
\text { Feeling! ...I } \\
\text { Must Be Shutting } \\
\text { Up Like A } \\
\text { Telescope. }\end{array}$ & $\begin{array}{l}\text { If I Am Feeling } \\
\text { Like That, } \\
\text { Then I Must } \\
\text { Be Shutting Up } \\
\text { Like A } \\
\text { Telescope. }\end{array}$ & $\begin{array}{l}P Q \\
P Q\end{array}$ & $\begin{array}{l}\text { Modus } \\
\text { Ponens }\end{array}$ & Valid & $\begin{array}{l}\text { Emphasizing The } \\
\text { Relation } \\
\text { Between } \\
\text { Feelings And } \\
\text { Body Changes }\end{array}$ & Syntactic \\
\hline $\begin{array}{l}6 \\
\text { (P.16) }\end{array}$ & $\begin{array}{l}\text { Well, I'll Eat It, } \\
\text { And If It Makes } \\
\text { Me Grow }\end{array}$ & $\begin{array}{l}\text { If I Eat It, It } \\
\text { Will Make Me } \\
\text { Grow Larger }\end{array}$ & $\begin{array}{l}P Q \\
\frac{P}{Q}\end{array}$ & $\begin{array}{l}\text { Modus } \\
\text { Ponens }\end{array}$ & Valid & $\begin{array}{l}\text { Emphasizing } \\
\text { That Size } \\
\text { Doesn't Matter }\end{array}$ & Syntactic \\
\hline
\end{tabular}


Larger... I Can Or Smaller,

Creep Under The Which Both

Door.

$7 \quad$...I Must Have

(P.17) Been Changed

For Mabel

$\begin{array}{ll}8 & \text { How Can I Have } \\ \text { (P.17) } & \text { Done That? I }\end{array}$

Must Be

Growing Small

Again.

9

(P.18) Was So Small As

This Before...I

Declare It's Too

Bad.

$10 \quad$ Would It Be Of

(P.18) Any Use...To

Speak To This

Mouse?

Everything Is So

Out-Of-The-Way

Down Here, That

I Should Think

Very Likely It

Can Talk

11 I Wish I Had Our

(P.21) Dinah

Here...She'd

Soon Fetch It

Back!

12 How Surprised

(P.21) He'll Be When

He Finds Out

Who I Am!

13 Only I Don't

(P.22) Think, That

They'd Let Dinah

Stop In The

House If It

Began Ordering

People About

Like That!

14 I Should Have

(P.24) Liked Teaching

It Tricks Very

Much, If-If I'd

Only Been The

Right Size To Do

It!

\section{Are Useful.}

Then

I Am Must

To Mable

If I Could

I Must Be

Again.

If I Am So

Small, Then

If Being

Strange Is

Normal In

Wonderland,

Mouse Is

Normal

If Dinah Is

Here, Then

She'll Fetch

The Mouse

Back.

Who I Am,

Then

He Will Be

Surprised

Ordering

Like That,

Then

(Big Size),

Have Liked

Puppy Some
If I Couldn't

Answer Math,

$\begin{array}{lll}P Q & \text { Modus } & \text { Valid } \\ P & \text { Ponens } & \end{array}$

Have Changed

Wear Rabbit's

Gloves, Then

Growing Small

It Is Too Bad

(And Speaking

To A Mouse Is

Strange), Then

Speaking To A

If He Knows

If Dinah Began

People About

They Wouldn't

Let Dinah Stop

In The House

If I Had Been

The Right Size

Then I Should

Teaching The

Tricks.

$\frac{P}{Q}$

Modus Valid

$P Q \quad$ Modus Valid

$P Q$ Modus Valid

$\frac{P}{Q} \quad$ Ponens

$P Q$ Modus Invalid

$\frac{\sim P}{\sim Q}$

Ponens

$P Q \quad$ Modus

$P Q \quad$ Modus

$\frac{\sim P}{\sim Q}$

Ponens
As Long As It

Fits.

Questioning

Identity (Based

On Knowledge)

Syntactic

Criticizing

Human Nature

(Body Changes)

Syntactic

Criticizing Social

Syntactic

Values

(Being Small Is

Bad)

Criticizing

Social Values

(What Is Strange)

Syntactic

$\begin{array}{lll}P Q & \text { Modus } & \text { Invalid } \\ \frac{\sim P}{\sim Q} & \text { Ponens } & \end{array}$

Emphasizing

That Wishes Are

Of No Use

Criticizing Pride

On Identity

Invalid

Criticizing

Authority And

Power (Relation

Between The

Strong The

Weak, People

And

Government)

Invalid

Criticizing Social

Values (People

Of Big Size Has

Power Over

Those Of Small

Size)
Syntactic

Syntactic

Syntactic

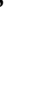

Syntactic 


\begin{tabular}{|c|c|c|c|c|c|c|c|}
\hline $\begin{array}{l}15 \\
\text { (P.30) }\end{array}$ & $\begin{array}{l}\text { If You're Going } \\
\text { To Turn Into A } \\
\text { Pig, My Dear, I'll } \\
\text { Have Nothing } \\
\text { More To Do } \\
\text { With You }\end{array}$ & $\begin{array}{l}\text { If You're } \\
\text { Going To Turn } \\
\text { Into A Pig, } \\
\text { Then I'll Have } \\
\text { Nothing More } \\
\text { To Do With } \\
\text { You }\end{array}$ & $\begin{array}{l}P Q \\
\frac{P}{Q}\end{array}$ & $\begin{array}{l}\text { Modus } \\
\text { Ponens }\end{array}$ & Valid & $\begin{array}{l}\text { Criticizing The } \\
\text { Human Nature } \\
\text { (The Animal } \\
\text { Aspect Of } \\
\text { Humans) }\end{array}$ & Syntactic \\
\hline $\begin{array}{l}16 \\
\text { (P.31) }\end{array}$ & $\begin{array}{l}\text { If There Is Not } \\
\text { Any Wine, Then } \\
\text { It Wasn't Very } \\
\text { Civil Of You To } \\
\text { Offer It }\end{array}$ & $\begin{array}{l}\text { If There Is No } \\
\text { Wine, It } \\
\text { Wasn't Not } \\
\text { Civil To Offer } \\
\text { It }\end{array}$ & $\begin{array}{l}P Q \\
P Q\end{array}$ & $\begin{array}{l}\text { Modus } \\
\text { Ponens }\end{array}$ & Valid & $\begin{array}{l}\text { Criticizing The } \\
\text { Human Nature } \\
\text { (Etiquette ) }\end{array}$ & Syntactic \\
\hline $\begin{array}{l}17 \\
\text { (P.34) }\end{array}$ & $\begin{array}{l}\text {...I've Had } \\
\text { Nothing Yet, So I } \\
\text { Can't Take } \\
\text { More."... }\end{array}$ & $\begin{array}{l}\text { If I Had } \\
\text { Nothing Yet, } \\
\text { Then } \\
\text { I Cannot Take } \\
\text { More }\end{array}$ & $\begin{array}{l}P Q \\
\frac{P}{Q}\end{array}$ & $\begin{array}{l}\text { Modus } \\
\text { Ponens }\end{array}$ & Valid & $\begin{array}{l}\text { Emphasizing The } \\
\text { Importance Of } \\
\text { Zero In } \\
\text { Mathematics }\end{array}$ & Syntactic \\
\hline $\begin{array}{l}18 \\
\text { (P.39) }\end{array}$ & $\begin{array}{l}\text { I Don't See How } \\
\text { He Can Ever } \\
\text { Finish, If He } \\
\text { Doesn't Begin. }\end{array}$ & $\begin{array}{l}\text { If He Doesn't } \\
\text { Begin, Then } \\
\text { He Cannot } \\
\text { Finish }\end{array}$ & $\begin{array}{l}P Q \\
\frac{P}{Q}\end{array}$ & $\begin{array}{l}\text { Modus } \\
\text { Ponens }\end{array}$ & Valid & $\begin{array}{l}\text { Emphasizing The } \\
\text { Importance Of } \\
\text { Logic }\end{array}$ & Syntactic \\
\hline $\begin{array}{l}19 \\
(\text { P.39) }\end{array}$ & $\begin{array}{l}\text { I Think I Should } \\
\text { Understand That } \\
\text { Better, If I Had It } \\
\text { Written Down }\end{array}$ & $\begin{array}{l}\text { If I Had It } \\
\text { Written Down, } \\
\text { Then I Should } \\
\text { Understand } \\
\text { That Better }\end{array}$ & $\begin{array}{l}P Q \\
\sim P \\
\sim Q\end{array}$ & $\begin{array}{l}\text { Modus } \\
\text { Ponens }\end{array}$ & Invalid & $\begin{array}{l}\text { Criticizing } \\
\text { Human } \\
\text { Capability To } \\
\text { Comprehend } \\
\text { Logic And } \\
\text { Language. }\end{array}$ & Syntactic \\
\hline $\begin{array}{l}20 \\
(\mathrm{P} .42)\end{array}$ & $\begin{array}{l}\text { If I'd Been The } \\
\text { Whiting, I'd } \\
\text { Have Said To } \\
\text { The Porpoise } \\
\text { 'Keep Back, } \\
\text { Please! }\end{array}$ & $\begin{array}{l}\text { If I'd Been The } \\
\text { Whiting, Then } \\
\text { I'd Have Said } \\
\text { To The } \\
\text { Porpoise...'Ke } \\
\text { ep Back, } \\
\text { Please! }\end{array}$ & $\begin{array}{l}P Q \\
\sim P \\
\sim Q\end{array}$ & $\begin{array}{l}\text { Modus } \\
\text { Ponens }\end{array}$ & Invalid & $\begin{array}{l}\text { Emphasizing The } \\
\text { Importance Of } \\
\text { Objection And } \\
\text { Expressing One's } \\
\text { Opinion Freely }\end{array}$ & Syntactic \\
\hline $\begin{array}{l}21 \\
(\mathbf{P . 4 7 )}\end{array}$ & $\begin{array}{l}\text {...Then It Ought } \\
\text { To Be Number } \\
\text { One. }\end{array}$ & $\begin{array}{l}\text { If It's The } \\
\text { Oldest Rule In } \\
\text { The Book, } \\
\text { Then It Ought } \\
\text { To Be Number } \\
\text { One } \\
\text { Table } 2 \text { Hypo }\end{array}$ & $\begin{array}{l}P Q \\
P \\
Q\end{array}$ & $\begin{array}{l}\text { Modus } \\
\text { Ponens }\end{array}$ & Valid & $\begin{array}{l}\text { Emphasizing The } \\
\text { Importance Of } \\
\text { Logic And } \\
\text { Mathematics }\end{array}$ & Syntactic \\
\hline $\begin{array}{l}\text { No. } \\
\text { And } \\
\text { Page }\end{array}$ & Utterance & Analysis & $\begin{array}{l}\text { Formul } \\
\text { a }\end{array}$ & Rule & Validity & $\begin{array}{l}\text { Semantic } \\
\text { Implications }\end{array}$ & Type \\
\hline $\begin{array}{l}1 \\
\text { (P.16) }\end{array}$ & $\begin{array}{l}\text { If It Makes Me } \\
\text { Grow Larger, I } \\
\text { Can Reach The } \\
\text { Key }\end{array}$ & $\begin{array}{l}\text { If It Makes } \\
\text { Me Larger, } \\
\text { Then I'll } \\
\text { Reach The } \\
\text { Key } \\
\text { If I'll Reach } \\
\text { The Key } \\
\text { I'll Open } \\
\text { The Door }\end{array}$ & $\begin{array}{l}P \rightarrow \mathrm{Q} \\
Q \rightarrow \mathrm{R} \\
P \rightarrow \mathrm{R}\end{array}$ & $\begin{array}{l}\text { Hypothe } \\
\text { tical } \\
\text { Syllogis } \\
\mathrm{m}\end{array}$ & Valid & $\begin{array}{l}\text { Criticizing The } \\
\text { Famous Saying } \\
\text { "The End } \\
\text { Justifies The } \\
\text { Means" }\end{array}$ & Syntactic \\
\hline
\end{tabular}


2

(P.16)

If It Makes Me

Grow Smaller, I

Can Creep Under I'l

The Door

\section{Unc}

$\begin{array}{lr}\text { If I'll } & \text { Creep } \\ \text { Under The } & \text { The } \\ \text { Door, I'll }\end{array}$

Get Into The

Garden

3 I Shall Be A If I'm Too

(P.16) Great Deal Too Far Off To Trouble Myself About You

If I'm A

A

If
Far Off,

Great Deal

Great Deal,

I'll Not

Trouble

Myself

About You

$4 \quad$...But I Must Be If I'm A Big

(P.16) Kind To

Them...I'll Give

Them A New

Pair Of Boots

Every Christmas.

Deal, I Must

Be Kind To

Them

$P \rightarrow Q \quad$ Hypothe Valid

Criticizing

The Famous

Saying

"The End

Justifies The

Means"

$\begin{array}{llll}P \rightarrow \mathrm{Q} & \text { Hypothe } & \text { Valid } & \begin{array}{l}\text { Criticizing } \\ Q \rightarrow \mathrm{R}\end{array} \\ \text { tical } & & \text { Authority }\end{array}$

$\begin{array}{llll}P \rightarrow \mathrm{Q} & \text { Hypothe } & \text { Valid } & \text { Criticizing } \\ Q \rightarrow \mathrm{R} & \text { tical } & & \text { Authority }\end{array}$

Syllogis

$\mathrm{m}$

$P \rightarrow \mathrm{Q}$ Hypothe Valid

Criticizing

Authority And

Religion

(Christmas

Presents)

If I'm Kind

To Them,

$Q \rightarrow \mathrm{R}$ tical

Syllogis

$\mathrm{m}$
Syntactic

I'll Give

Them A

New Boots

Every

Christmas

5 They Must Go If I'll Send

(P.16) By The Carrier, And How Funny

It'll Seem...Odd

The Direction

Will Look!

Them Boots,

It'll Be By

The Carrier

If I'll Send

Them By

$P \rightarrow \mathrm{Q}$ Hypothe Valid

$Q \rightarrow \mathrm{R}$ tical

Syllogis

$\overline{P \rightarrow \mathrm{R}} \mathrm{m}$

Carrier, That

Will Be

Funny And

Odd

6 Besides, She's If She Is She,

(P.17)

$P \rightarrow \mathrm{Q}$

Hypothe Valid

Questioning Identity (Based

And-Oh Dear, She Is Not I

$Q \rightarrow \mathrm{R}$

tical

Syllogis

On Linguistic

How Puzzling It

All Is!

If She Is Not

$\overline{P \rightarrow \mathrm{R}} \mathrm{m}$

References)

I Am I

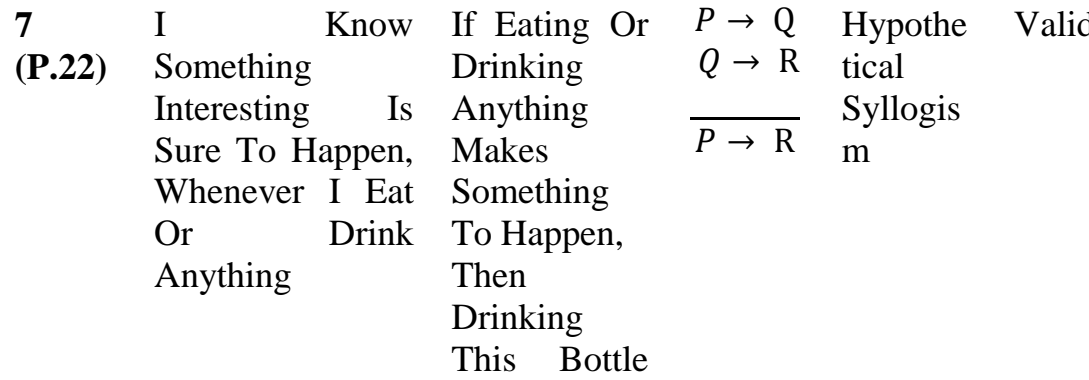

Criticizing

Human Nature

(Body Changes

(Relating

Eating And

Drinking To

Growth) 
Will Make

Something

To Happen,

If It'll Make

Something

To Happen,

Then It

Might Make

Me Grow

Large Again

8 ...That'll Be A If I'll Never

(P.22) Comfort, One Get Older,

Way-Never To Then I'll

$\mathrm{Be}$

Never Be An

An Old Woman Old Woman

If I'll Never

Be An Old

Woman,

Then It'll Be

Comfort

9 If I Eat One Of

(P.23) These Cakes, It's

Sure To Make

Some Change In

My Size And, As

It Can't Possibly

Make Me Larger,

It Must Make Me

Smaller.

If I Eat One

Of These

Cakes, Then

It'll Make

Some

Change In

My Size,

If It'll Make

Some

Change In

My Size,

Then, It

Must Make

Me Smaller

10 What Would Be If People

(P.35) The Use Of A

Procession...If

People Had All

To Lie Down On

Their Faces, So

That They

Couldn't See It?"

Had All To

Lie Down

On Their

Faces, Then

They'll Not

See The

Procession

If They'll

Not See It,

Then It Will

Be Of No

Use

$\begin{array}{llr}\text { 11 } & \text { Then } & \text { The } \\ \text { (P.40) } & \text { Eleventh } & \text { Day } \\ & \text { Must Have Been }\end{array}$

A Holiday?"

If Lessons

And There

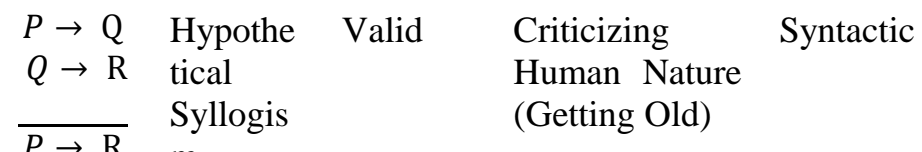

\begin{tabular}{|c|c|c|c|}
\hline & \multirow{6}{*}{$\begin{array}{l}\text { Hypothe } \\
\text { tical } \\
\text { Syllogis } \\
\mathrm{m}\end{array}$} & \multirow[t]{6}{*}{ Valid } & \multirow{3}{*}{$\begin{array}{l}\text { Criticizing } \\
\text { Human Nature } \\
\text { (Body Changes } \\
\text { (Relating }\end{array}$} \\
\hline & & & \\
\hline$\overline{P \rightarrow \mathrm{R}}$ & & & \\
\hline & & & Eating \\
\hline & & & Drinking \\
\hline & & & Growth) \\
\hline
\end{tabular}

\begin{tabular}{llll}
$P \rightarrow \mathrm{Q}$ & Hypothe & Valid & Criticizing \\
$Q \rightarrow \mathrm{R}$ & tical & & Authority And \\
& Syllogis & & Politics \\
\hline$P \rightarrow \mathrm{R}$ & $\mathrm{m}$ & (Particularly \\
& & Formal Rituals \\
& & And Customs)
\end{tabular}

$P \rightarrow \mathrm{Q}$ Hypothe Valid

$Q \rightarrow \mathrm{R}$ tical

Day To Day

$\overline{P \rightarrow \mathrm{R}} \begin{aligned} & \text { Syllogis } \\ & \mathrm{m}\end{aligned}$

Are Ten

Hours On

The First

Day, Then

There Is No 


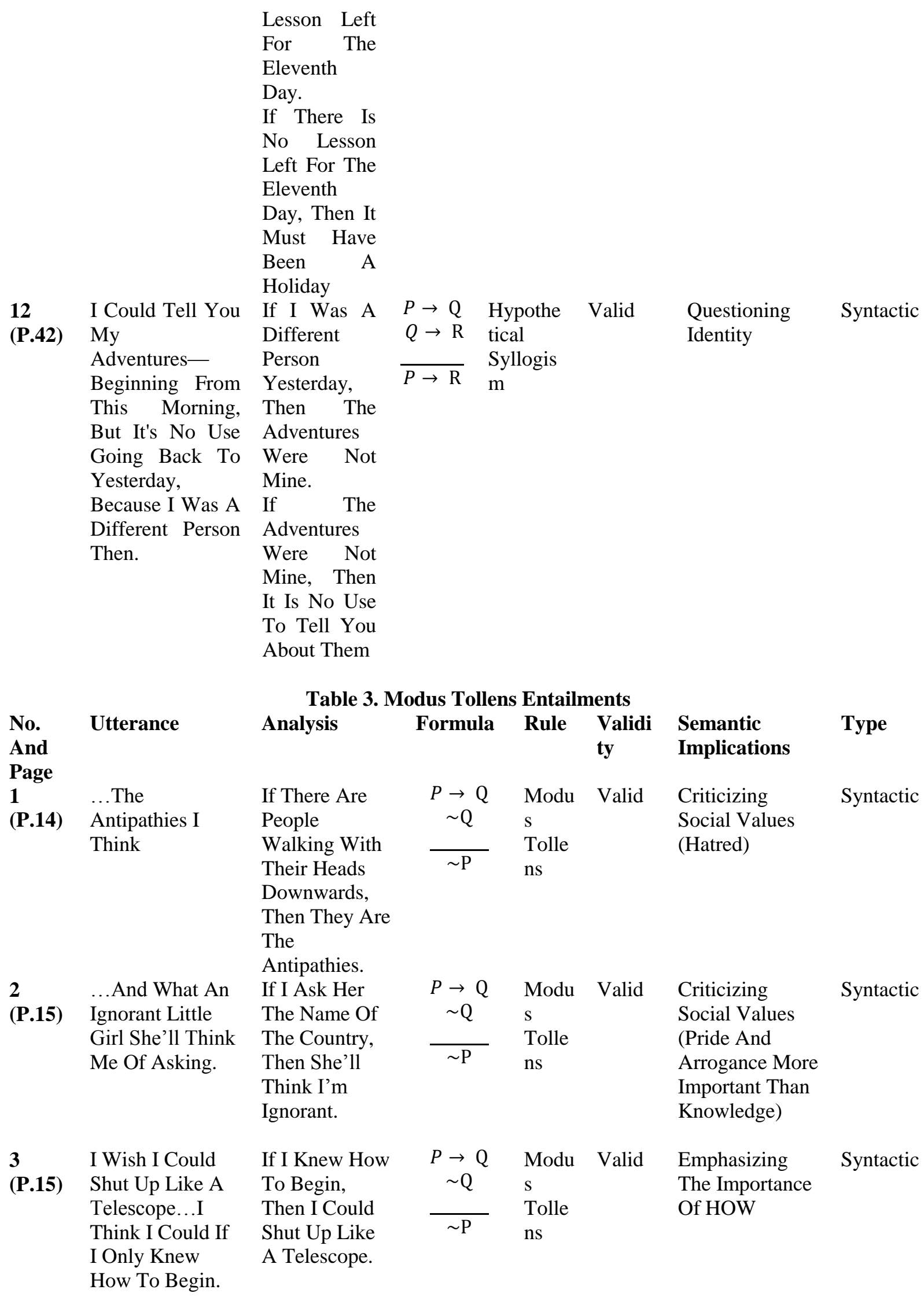




\begin{tabular}{|c|c|c|c|c|c|c|c|}
\hline $\begin{array}{l}4 \\
(\mathbf{P} .17)\end{array}$ & $\begin{array}{l}\text { I'm Sure I'm Not } \\
\text { Ada...For Her } \\
\text { Hair Goes In } \\
\text { Such Long } \\
\text { Ringlets }\end{array}$ & $\begin{array}{l}\text { If I Am Ada, } \\
\text { Then My Hair } \\
\text { Must Go In } \\
\text { Such Long } \\
\text { Ringlets }\end{array}$ & $\begin{array}{l}P \rightarrow \mathrm{Q} \\
\stackrel{\sim Q}{ } \\
\sim \mathrm{P}\end{array}$ & $\begin{array}{l}\text { Modu } \\
\text { s } \\
\text { Tolle } \\
\text { ns }\end{array}$ & Valid & $\begin{array}{l}\text { Questioning } \\
\text { Identity (Based } \\
\text { On Beauty) }\end{array}$ & Syntactic \\
\hline $\begin{array}{l}5 \\
(\mathbf{P . 1 7})\end{array}$ & $\begin{array}{l}\text { I Can't Be } \\
\text { Mabel, For I } \\
\text { Know All Sorts } \\
\text { Of Things, And } \\
\text { She... Knows } \\
\text { Such A Very } \\
\text { Little! }\end{array}$ & $\begin{array}{l}\text { If Am Mable, } \\
\text { Then I Must } \\
\text { Know Little }\end{array}$ & $\begin{aligned} & P \rightarrow Q \\
& \sim Q \\
& \sim P\end{aligned}$ & $\begin{array}{l}\text { Modu } \\
\text { S } \\
\text { Tolle } \\
\text { ns }\end{array}$ & Valid & $\begin{array}{l}\text { Questioning } \\
\text { Identity (Based } \\
\text { On Knowledge) }\end{array}$ & Syntactic \\
\hline $\begin{array}{l}6 \\
(P .18)\end{array}$ & $\begin{array}{l}\text {...But It Said } \\
\text { Nothing. } \\
\text { "Perhaps It } \\
\text { Doesn't } \\
\text { Understand } \\
\text { English" }\end{array}$ & $\begin{array}{l}\text { If It Said } \\
\text { Nothing, Then } \\
\text { It Doesn't } \\
\text { Understand } \\
\text { English }\end{array}$ & $\begin{array}{l}P \rightarrow Q \\
\sim Q Q \\
\sim P\end{array}$ & $\begin{array}{l}\text { Modu } \\
\text { S } \\
\text { Tolle } \\
\text { ns }\end{array}$ & Valid & $\begin{array}{l}\text { Emphasizing } \\
\text { That Silence } \\
\text { Has Meaning }\end{array}$ & Syntactic \\
\hline $\begin{array}{l}7 \\
\text { (P.23) }\end{array}$ & $\begin{array}{l}\text {...If They Had } \\
\text { Any Sense, } \\
\text { They'd Take The } \\
\text { Roof Off }\end{array}$ & $\begin{array}{l}\text { If They Had } \\
\text { Any Sense, } \\
\text { Then They'd } \\
\text { Take The Roof } \\
\text { Off }\end{array}$ & $\begin{aligned} P & \rightarrow Q \\
& \sim Q \\
& \sim P\end{aligned}$ & $\begin{array}{l}\text { Mode } \\
\text { S } \\
\text { Tolle } \\
\text { ns }\end{array}$ & Valid & $\begin{array}{l}\text { Criticizing } \\
\text { Stupidity By } \\
\text { Creating Humor }\end{array}$ & Syntactic \\
\hline
\end{tabular}

\begin{tabular}{|c|c|c|c|c|c|c|c|}
\hline $\begin{array}{l}\text { No. } \\
\text { And }\end{array}$ & Utterance & Analysis & Formul & $\begin{array}{l}\operatorname{logism} \mathrm{Er} \\
\text { Rule }\end{array}$ & $\begin{array}{l}\text { Validi } \\
\text { ty }\end{array}$ & $\begin{array}{l}\text { Semantic } \\
\text { Implications }\end{array}$ & Type \\
\hline $\begin{array}{l}1 \\
\text { (P.15) }\end{array}$ & $\begin{array}{l}\text { But Do Cats Eat } \\
\text { Bats, I } \\
\text { Wonder...Do } \\
\text { Bats Eat Cats? }\end{array}$ & $\begin{array}{l}\text { Cats Eat Bats } \\
\text { Or Bats Eat } \\
\text { Cats }\end{array}$ & $\begin{array}{l}P \vee Q \\
\sim P \\
\frac{Q}{Q}\end{array}$ & $\begin{array}{l}\text { Disjuncti } \\
\text { ve } \\
\text { Syllogis } \\
\mathrm{m}\end{array}$ & Invalid & $\begin{array}{l}\text { Questioning } \\
\text { Meanings (Both } \\
\text { Reference And } \\
\text { Sense) }\end{array}$ & $\begin{array}{l}\text { Syntacti } \\
\mathrm{c}\end{array}$ \\
\hline $\begin{array}{l}2 \\
(\text { P.16) }\end{array}$ & $\begin{array}{l}\text {...But I Must Be } \\
\text { Kind To Them } \\
\text { Or Perhaps They } \\
\text { Will Not Walk } \\
\text { The Way I Want } \\
\text { To Go }\end{array}$ & $\begin{array}{l}\text { If I'm Not } \\
\text { Kind To } \\
\text { Them They } \\
\text { Will Not } \\
\text { Walk The } \\
\text { Way I Want }\end{array}$ & $\begin{array}{l}P \vee Q \\
\sim P \\
Q\end{array}$ & $\begin{array}{l}\text { Disjuncti } \\
\text { ve } \\
\text { Syllogis } \\
\mathrm{m}\end{array}$ & Valid & $\begin{array}{l}\text { Criticizing } \\
\text { Politics }\end{array}$ & $\begin{array}{l}\text { Syntacti } \\
\mathrm{c}\end{array}$ \\
\hline $\begin{array}{l}3 \\
\text { (P.17) }\end{array}$ & $\begin{array}{l}\text { If I'm Not The } \\
\text { Same... Who In } \\
\text { The World Am } \\
\text { I? }\end{array}$ & $\begin{array}{l}\text { If I Was The } \\
\text { Same, Then } \\
\text { I'm Alice } \\
\text { If I Wasn't } \\
\text { The Same, } \\
\text { Then I'm Not } \\
\text { Alice } \\
\text { (Am I Alice } \\
\text { Or Am I Not } \\
\text { Alice?) }\end{array}$ & $\begin{array}{l}P \vee Q \\
\sim P \\
Q\end{array}$ & $\begin{array}{l}\text { Disjuncti } \\
\text { ve } \\
\text { Syllogis } \\
\mathrm{m}\end{array}$ & Valid & $\begin{array}{l}\text { Questioning } \\
\text { Identity In Light } \\
\text { Of Repeated } \\
\text { Changes }\end{array}$ & $\begin{array}{l}\text { Syntacti } \\
\mathrm{c}\end{array}$ \\
\hline $\begin{array}{l}4 \\
(\mathbf{P} .23)\end{array}$ & $\begin{array}{l}\text {...If You Do, I'll } \\
\text { Set Dinah On } \\
\text { You. }\end{array}$ & $\begin{array}{l}\text { You Will Not } \\
\text { Burn The } \\
\text { House, Or I'1l } \\
\text { Set Dinah On } \\
\text { You. }\end{array}$ & $\begin{array}{l}P \vee Q \\
\sim P \\
\frac{Q}{Q}\end{array}$ & $\begin{array}{l}\text { Disjuncti } \\
\text { ve } \\
\text { Syllogis } \\
\mathrm{m}\end{array}$ & Valid & $\begin{array}{l}\text { Criticizing } \\
\text { Authority And } \\
\text { The Use Of } \\
\text { Power (Threats) }\end{array}$ & $\begin{array}{l}\text { Syntacti } \\
\mathrm{c}\end{array}$ \\
\hline
\end{tabular}


5

(P.30) This Child Away

This Child Away

With Me, They're

Sure To Kill It In

A Day Or Two

$\begin{array}{ll}\text { 6 } & \text { They Couldn't } \\ \text { (P.34) } & \text { Have Done } \\ & \text { That...They'd } \\ & \text { Have Been Ill. }\end{array}$

If I Will Not

Take This

Child Away

With Me,

They'll Kill It

(I'll Take It

Or They Will

Kill It)

If They Lived

On Treacle,

Then They

Would Have

Been Ill

(They Would

Not Live On

Treacle Or

They Would

Have Been

Ill)

$\begin{array}{cllll}P \vee Q & \text { Disjuncti } & \text { Valid } & \text { Criticizing } & \text { Syntacti } \\ \sim P & \text { ve } & & \text { Human Justice } & \mathrm{c} \\ & \text { Syllogis } & & & \\ \mathrm{Q} & \mathrm{m} & & & \end{array}$

\begin{tabular}{|c|c|}
\hline $\begin{array}{l}P \vee Q \\
\sim P\end{array}$ & Disjuncti \\
\hline & $\begin{array}{l}\text { Syllogis } \\
\mathrm{m}\end{array}$ \\
\hline
\end{tabular}

Criticizing Syntacti

Human Nature

(The Need To

Eat Various Kind

Of Food) 